\title{
Effect of Zirconia Nanofibers Structure Evolution on the Hardness and Young's Modulus of Their Mats
}

\author{
Vyacheslav V. Rodaev *, Alexander I. Tyurin, Svetlana S. Razlivalova, Viktor V. Korenkov and Yuri I. Golovin
}

Citation: Rodaev, V.V.; Tyurin, A.I.; Razlivalova, S.S.; Korenkov, V.V.; Golovin, Y.I. Effect of Zirconia Nanofibers Structure Evolution on the Hardness and Young's Modulus of Their Mats. Polymers 2021, 13, 3932. https://doi.org/10.3390/ polym13223932

Academic Editor: Suman Sinha Ray

Received: 25 October 2021

Accepted: 12 November 2021

Published: 14 November 2021

Publisher's Note: MDPI stays neutral with regard to jurisdictional claims in published maps and institutional affiliations.

Copyright: (c) 2021 by the authors. Licensee MDPI, Basel, Switzerland. This article is an open access article distributed under the terms and conditions of the Creative Commons Attribution (CC BY) license (https:// creativecommons.org/licenses/by/ $4.0 /)$.
Institute for Nanotechnology and Nanomaterials, Derzhavin Tambov State University, Internatsionalnaya str. 33, 392000 Tambov, Russia; tyurin@tsu.tmb.ru (A.I.T.); razlivalova8@yandex.ru (S.S.R.); ya.vikkor@yandex.ru (V.V.K.); golovin@tsu.tmb.ru (Y.I.G.)

* Correspondence: rodaev1980@mail.ru; Tel.: +7-910-6522328; Fax: +7-475-2532680

\begin{abstract}
Zirconia nanofiber mats containing filaments with the average diameter of less than $100 \mathrm{~nm}$ were fabricated. It is found that the hardness and Young's modulus of the mats are sensitive to the microstructure, phase composition and average diameter of the zirconia nanofibers. The hardness and Young's modulus of the prepared zirconia nanofiber mats vary from 0.86 to $1.67 \mathrm{MPa}$ and from 133 to $362 \mathrm{MPa}$, respectively, wherein an increase in hardness is accompanied by the rise in Young's modulus.
\end{abstract}

Keywords: zirconia nanofibers; electrospinning; microstructure; phase composition; mechanical characteristics; nanoindentation

\section{Introduction}

Among all the variety of nanofibers only ceramic ones possess increased thermal and chemical resistance [1,2]. Electrospinning is a cost effective and simple method for the large scale production of ceramic nanofibers of controllable composition and diameter $[1,2]$. The process of ceramic nanofibers fabrication by electrospinning consists of the following three stages: preparation of the solution containing ceramic precursor and binding polymer, hybrid fibers electrospinning, drying and annealing hybrid fibers to obtain ceramic nanofibers. Nanofibers produced by electrospinning tend to form mats.

Zirconia and its precursors are widely used to obtain different advanced ceramic materials [3]. Pure zirconia exhibits three allotropic modifications: low-temperature monoclinic $\left(\mathrm{m}-\mathrm{ZrO}_{2}\right)$ and high-temperature tetragonal $\left(\mathrm{t}-\mathrm{ZrO}_{2}\right)$ and cubic $\left(\mathrm{c}-\mathrm{ZrO}_{2}\right)$ [4]. However, $\mathrm{t}-\mathrm{ZrO}_{2}$ and $\mathrm{c}-\mathrm{ZrO}_{2}$ phases can exist at room temperature if the stabilizer is introduced into pure zirconia in the required amounts. Yttria is one of metal oxides commonly used as a stabilizer. It is well known that the mechanical characteristics of bulk zirconia ceramics can be significantly improved by adding $3 \mathrm{~mol} \% \mathrm{Y}_{2} \mathrm{O}_{3}$ to pure zirconia to obtain tetragonal zirconia polycrystalline ceramics [4].

Zirconia nanofiber mats are ceramic nanofiber mats with a wide range of possible applications as scaffolds for solid oxide fuel cells cathodes $[5,6]$, separators for high-power rechargeable batteries [7], filters and adsorbents [8-11], catalysts [12-14], gas sensors [15], bone tissue regeneration scaffolds [16], shape-memory material for artificial muscle applications [17], electromagnetic interference shielding [18], an element of a light-sensitive photodetector [19], electrode material for electrochemical devices [20], etc.

However, the functional properties of mats depend on the diameter, grain structure, phase composition and porosity of the nanofiber components. There are several ways to control the microstructure and phase composition of zirconia nanofibers via varying the calcination temperature [21], dopant concentration [22] and zirconia precursor content in the composite intermediate filaments [23].

For any zirconia nanofiber mat application the mechanical characteristics are important. Tensile testing is usually performed to obtain data on tensile stress, ultimate strain 
and Young's modulus of the ceramic nanofiber mats $[8,23,24]$. Nanoindentation, as the preferred method for testing thin film and surface mechanical characteristics, is another approach to examining the mechanical characteristics of nanofibrous mats, which allows defining their hardness and Young's modulus [25]. Young's modulus values obtained by a tensile test and nanoindentation will differ due to nanofibrous mats' anisotropy. The given mechanical characteristics are important if nanofibrous mats are under normal stress during operation, for example, acting as adsorbents, filters or catalysts in gas flows. Random orientation of the electrospun nanofibers and macroporous structure of the mats require using a spherical indenter with a curvature radius many times larger than the diameter of nanofibers and the size of macropores to obtain reliable values of hardness and Young's modulus for nanofibrous mats [26].

The aim of this work is to study the effect of zirconia nanofibers microstructure and phase composition on the mechanical characteristics of their mats, such as hardness and Young's modulus, using the nanoindentation method. To reveal the relationship between the morphology of zirconia nanofibers and the mechanical properties of the mats made from them is important for any practical use of the latter, and also provides prerequisites for fabricating nanofibrous materials with the required structure and functional properties.

\section{Materials and Methods}

The mats of zirconia nanofibers with the average diameter of less than $100 \mathrm{~nm}$ were prepared and characterized according to the scheme shown in Figure 1.

Preparation of spinnable solutions with different ZrAA/PAN mass ratios

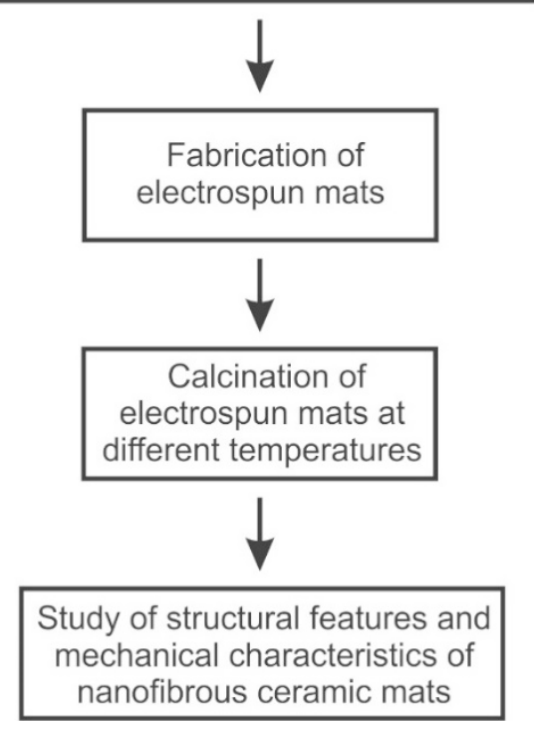

Figure 1. A schematic representation of the work methodology.

Polyacrylonitrile (PAN, molecular weight $\mathrm{Mw}=150,000$, Sigma-Aldrich, Saint Louis, MO, USA, $1 \mathrm{~g}$ ) was dissolved in N,N-dimethylformamide (DMF, Sigma-Aldrich, Saint Louis, MO, USA, $9 \mathrm{~g}$ ) under magnetic stirring for $2 \mathrm{~h}$ at $50{ }^{\circ} \mathrm{C}$ to prepare $10 \mathrm{wt} . \%$ polymer solution. Zirconium acetylacetonate (ZrAA, Sigma-Aldrich, Saint Louis, MO, USA, $0.3 \mathrm{~g}$ ) and yttrium nitrate hexahydrate (Sigma-Aldrich, Saint Louis, MO, USA, $0.015 \mathrm{~g}$ ) were added into the prepared polymer solution and stirred at $80^{\circ} \mathrm{C}$ until the solution became transparent. The amount of yttrium nitrate hexahydrate was such to obtain $3 \mathrm{~mol} \% \mathrm{Y}_{2} \mathrm{O}_{3}$ $\mathrm{ZrO}_{2}$ nanofibers. Composite solutions with $\mathrm{ZrAA} / \mathrm{PAN}$ mass ratios of 0.1:1, 0.2:1 and 0.3:1 were fabricated. 
The prepared composite solutions were poured into a $10 \mathrm{~mL}$ plastic syringe and then electrospun through a $23 \mathrm{G}$ blunt tip needle upon the rectangular frame collector made of copper wire placed in a NANON-01A electrospinning machine (MECC, Fukuoka, Japan). The fibers were collected as non-woven mats. The accelerating voltage of $18 \mathrm{kV}$, the distance between the needle tip and the collector of $15 \mathrm{~cm}$ and a feeding rate of $1 \mathrm{~mL} / \mathrm{h}$ were chosen to fabricate smooth and bead-free composite fibers.

The electrospun mats were calcined at different temperatures in air atmosphere between lightweight alumina plates with a smooth surface to prevent the mats wrinkling. Calcination was carried out in several stages in accordance with the performed thermogravimetric (TG) analysis and differential thermal (DT) analysis: heating to $320^{\circ} \mathrm{C}$ with a heating rate of $1{ }^{\circ} \mathrm{C} / \mathrm{min}$, holding at $320^{\circ} \mathrm{C}$ for $1 \mathrm{~h}$, further heating to $600{ }^{\circ} \mathrm{C}$ with the same heating rate and holding at $600{ }^{\circ} \mathrm{C}$ for $1 \mathrm{~h}$ and finally heating to 700,900 or $1200{ }^{\circ} \mathrm{C}$ with a heating rate of $5{ }^{\circ} \mathrm{C} / \mathrm{min}$ and holding at the target temperature for $1 \mathrm{~h}$.

The TG analysis and DT analysis were performed on the thermal analyzer EXSTAR TG/DTA7200 (SII Nano Technology, Tokyo, Japan) in air atmosphere with a heating rate of $10{ }^{\circ} \mathrm{C} / \mathrm{min}$.

The microstructure and diameter of the fibers were examined with a Merlin scanning electron microscope (SEM, Carl Zeiss, Oberkochen, Germany). The XRD patterns were registered in the $2 \theta$ range $20-80^{\circ}$ by a D2 Phaser X-ray diffractometer (XRD, Bruker AXS, Karlsruhe, Germany) using CuK $\alpha 1$ monochromatic radiation and analyzed by means of the PDF-2 Diffraction Database File compiled by the International Centre for Diffraction. The phase content was determined from the XRD patterns by the Rietveld method using the TOPAS software (Bruker AXS) and the average grain size was also calculated in the TOPAS software (Bruker AXS) using the Scherrer equation. SEM and XRD measurements were carried out at room temperature. The specific surface area and the pore volume of the fibers were measured by nitrogen adsorption at $-196^{\circ} \mathrm{C}$ with a gas sorption analyzer Autosorb iQ-C (Quantachrome Instruments, Boynton Beach, FL, USA). The specific surface area was determined using Brunauer-Emmett-Teller method in a relative pressure range of 0.05-0.35. The pore volume was determined from the amount of nitrogen adsorbed at the relative pressure of 0.99 .

Nanoindentation measurements were carried out by a TI-950 nanotriboindenter (Bruker AXS) at room temperature using a stabilized zirconia spherical indenter with a radius of curvature of $250 \mu \mathrm{m}$. A constant strain rate of $0.05 \mathrm{~s}^{-1}$ was kept during all the tests. The load-displacement curves were obtained under peak load of $5 \mathrm{mN}$. Peak load was held for $10 \mathrm{~s}$ to stabilize the possible creep in the mat. At the end of unloading a hold of $15 \mathrm{~s}$ was provided to correct the thermal drift. The Poisson's ratio was about 0.25 . Young's modulus $(E)$ and hardness $(H)$ of the samples were calculated from the load-displacement curves using the Oliver-Pharr method [27]. The tested samples were carefully cut out from the fabricated zirconia nanofibrous mats and fixed with ethanol on the polished surface of $3 \mathrm{~mol} \% \mathrm{Y}_{2} \mathrm{O}_{3}-\mathrm{ZrO}_{2}$ ceramic pellets with Young's modulus of about $220 \mathrm{GPa}$ and hardness of about $14 \mathrm{GPa}$. The thickness of the tested samples was at least $50 \mu \mathrm{m}$.

\section{Results and Discussion}

The $3 \mathrm{~mol} \% \mathrm{Y}_{2} \mathrm{O}_{3}-\mathrm{ZrO}_{2}$ nanofibers calcined at $700{ }^{\circ} \mathrm{C}$ are cylindrical in shape, with a smooth surface (Figure $2 \mathrm{~b}$ ). Their average diameter is $79 \pm 7 \mathrm{~nm}$. The average diameter of the filaments calcined at $900^{\circ} \mathrm{C}$ is $72 \pm 6 \mathrm{~nm}$. No difference in the average diameters of the nanofibers calcined at 700 and $900{ }^{\circ} \mathrm{C}$ in the margin of error is associated with complete decomposition of $\mathrm{ZrAA}$ and PAN before $700{ }^{\circ} \mathrm{C}$ (Figure 2a). 

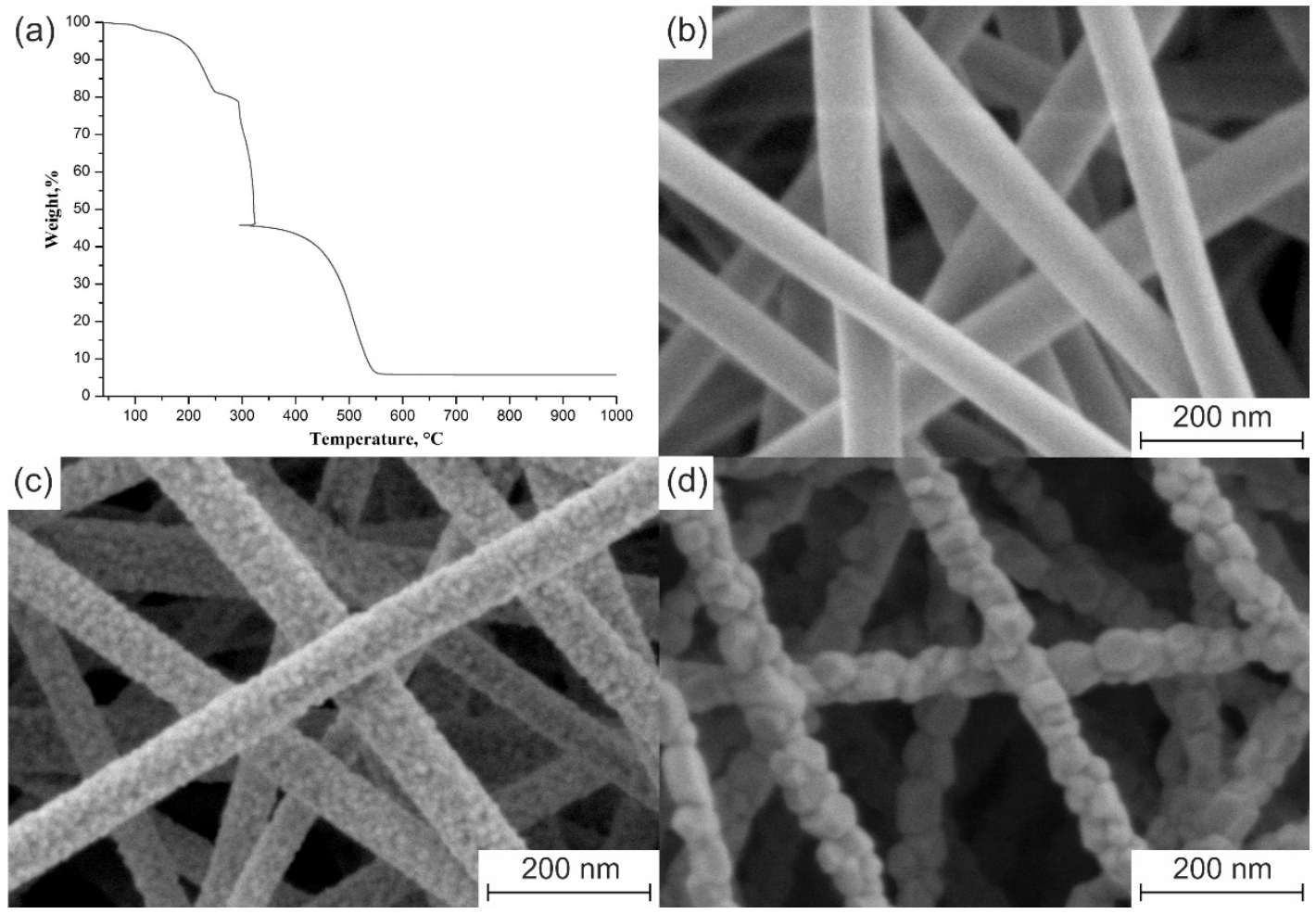

Figure 2. (a) TG curve of electrospun composite filaments with $\mathrm{ZrAA} / \mathrm{PAN}$ mass ratio of $0.3: 1$. The microstructure of $3 \mathrm{~mol} \%$ $\mathrm{Y}_{2} \mathrm{O}_{3}-\mathrm{ZrO}_{2}$ nanofibers prepared at: (b) $700{ }^{\circ} \mathrm{C}$; (c) $900{ }^{\circ} \mathrm{C}$; (d) $1100{ }^{\circ} \mathrm{C}$ from the composite filaments with $\mathrm{ZrAA} / \mathrm{PAN}$ mass ratio of 0.3:1.

An increase in calcination temperature from 700 to $900{ }^{\circ} \mathrm{C}$ stimulates $\mathrm{ZrO}_{2}$ grain growth that results in appearance of a rough nanofiber surface (Figure 2c). A calcination temperature increase to $1100{ }^{\circ} \mathrm{C}$ leads to further $\mathrm{ZrO}_{2}$ grains growth and also to a slight filaments shrinkage due to sintering. The average diameter of the nanofibers attains $68 \pm 4 \mathrm{~nm}$ and their surface becomes coarse (Figure 2d). The decrease in ZrAA/PAN mass ratio in the intermediate composite fibers from 0.3:1 to 0.1:1 results in the zirconia nanofibers average diameter reduction from $72 \pm 6$ to $52 \pm 5 \mathrm{~nm}$ if they are calcined at $900{ }^{\circ} \mathrm{C}$. It seems logical that a decrease in the mass ratio of the ceramic precursor to the binder polymer leads to a decrease in the thickness of the zirconia nanofibers, since the composite filaments containing no ZrAA do not form ceramic nanofibers. It should be noted that no carbon-containing nanofibers are formed during the composite filaments' calcination at elevated temperatures in air due to PAN burnout. To be carbonized the pre-stabilized PAN filaments must be calcined in an inert atmosphere [28].

The rise in the calcination temperature leads to the decrease in specific surface area of $3 \mathrm{~mol} \% \mathrm{Y}_{2} \mathrm{O}_{3}-\mathrm{ZrO}_{2}$ nanofibers (Table 1), which is associated with $\mathrm{ZrO}_{2}$ grain growth due to an intensification of the diffusion process. Small values of the pore volume allow classifying the prepared ceramic filaments as non-porous.

Table 1. The specific surface area and pore volume of $3 \mathrm{~mol} \% \mathrm{Y}_{2} \mathrm{O}_{3}-\mathrm{ZrO}_{2}$ nanofibers calcined at different temperatures.

\begin{tabular}{ccc}
\hline Calcination Temperature, ${ }^{\circ} \mathbf{C}$ & Specific Surface Area, $\mathbf{~ m}^{2} / \mathbf{g}$ & Pore Volume, $\mathbf{c m}^{3} / \mathbf{g}$ \\
\hline 700 & 23.6 & 0.051 \\
900 & 15.1 & 0.037 \\
1100 & 9.3 & 0.022 \\
\hline
\end{tabular}


The composite filaments with various $\mathrm{ZrAA} / \mathrm{PAN}$ mass ratios annealed at the same temperature produce $3 \mathrm{~mol} \% \mathrm{Y}_{2} \mathrm{O}_{3}-\mathrm{ZrO}_{2}$ nanofibers with a similar specific surface area.

Figure 3 shows the XRD patterns of $3 \mathrm{~mol} \% \mathrm{Y}_{2} \mathrm{O}_{3}-\mathrm{ZrO}_{2}$ nanofibers calcined at temperatures in the range of $700-1100{ }^{\circ} \mathrm{C}$. According to XRD patterns the fabricated filaments have crystalline structure and are composed purely of $\mathrm{t}-\mathrm{ZrO}_{2}$ grains since the observed reflections at $30.2^{\circ}, 35.2^{\circ}, 50.2^{\circ}$ and $60.2^{\circ}$ correspond to the main peaks specific for the $\mathrm{t}-\mathrm{ZrO}_{2}$ phase. With the rise in the calcination temperature the $\mathrm{t}-\mathrm{ZrO}_{2}$ peaks become sharper and narrower and the reflections at $34.6^{\circ}, 50.7^{\circ}$ and $59.3^{\circ}$ are visualized. It indicates that the crystallinity is higher and the grain size is larger for $3 \mathrm{~mol} \% \mathrm{Y}_{2} \mathrm{O}_{3}-\mathrm{ZrO}_{2}$ nanofibers fabricated at higher calcination temperatures. At calcination temperature of $700{ }^{\circ} \mathrm{C}$ the average $\mathrm{t}-\mathrm{ZrO}_{2}$ grain size is $9 \mathrm{~nm}$ and it becomes $18 \mathrm{~nm}$ if $900^{\circ} \mathrm{C}$ is used. Finally, the average $\mathrm{t}-\mathrm{ZrO}_{2}$ grain size attains $31 \mathrm{~nm}$ at the calcination temperature of $1100{ }^{\circ} \mathrm{C}$. SEM images confirm $\mathrm{ZrO}_{2}$ grain growth with an increase in the calcination temperature (Figure 2).

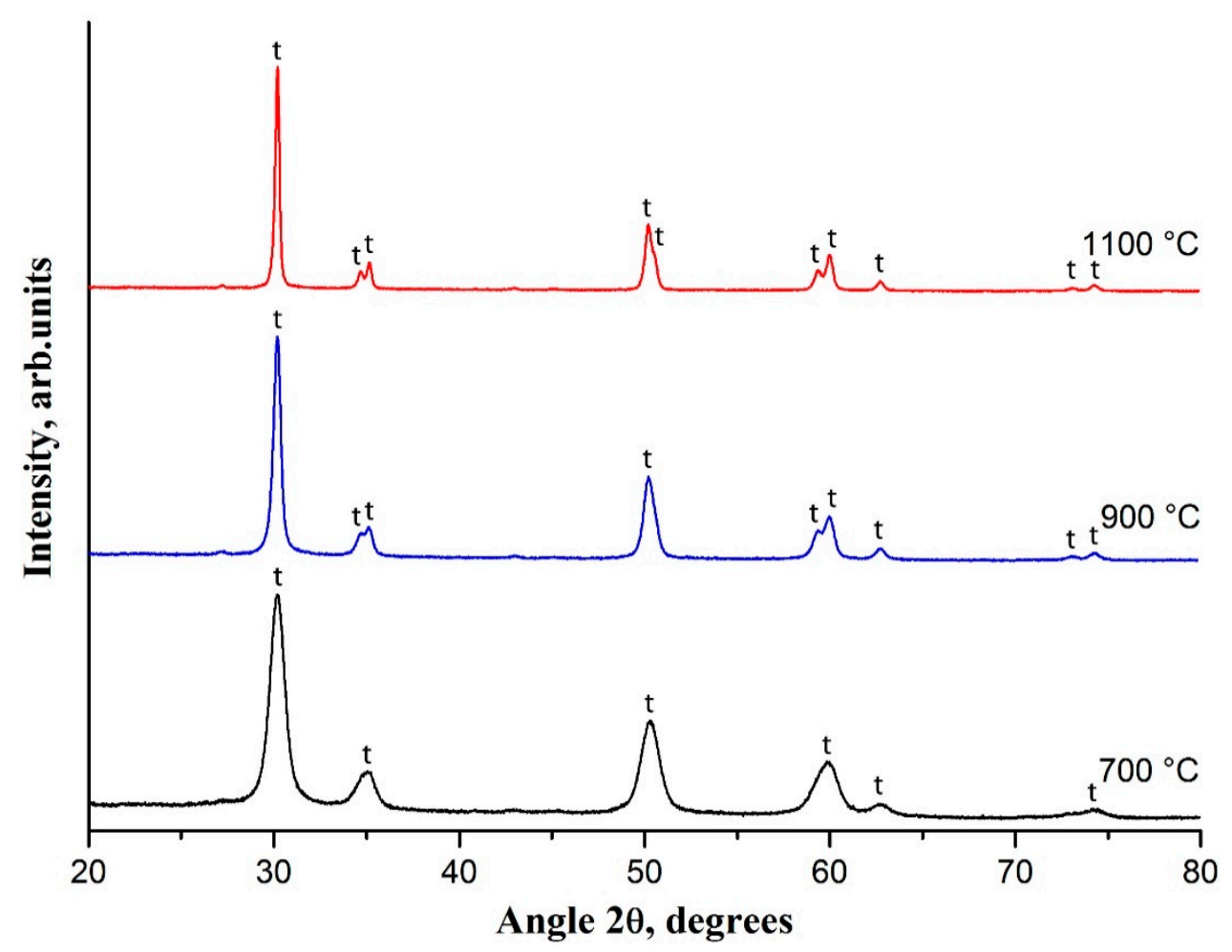

Figure 3. The $\mathrm{XRD}$ patterns of $3 \mathrm{~mol} \% \mathrm{Y}_{2} \mathrm{O}_{3}-\mathrm{ZrO}_{2}$ nanofibers prepared at 700,900 and $1100{ }^{\circ} \mathrm{C}$; t-tetragonal phase of $\mathrm{ZrO}_{2}$.

It is revealed that the decrease in $\mathrm{ZrAA} / \mathrm{PAN}$ mass ratio has no effect on the phase composition of the resulting $3 \mathrm{~mol} \% \mathrm{Y}_{2} \mathrm{O}_{3}-\mathrm{ZrO}_{2}$ nanofibers (Figure 4). Poorly visualized fine structure of the peaks near $35^{\circ}$ and $60^{\circ}$ in the XRD pattern of zirconia nanofibers prepared from composite filaments with ZrAA/PAN mass ratio of 0.1:1 may indicate a smaller size of $\mathrm{t}-\mathrm{ZrO}_{2}$ grains in the nanofibers obtained from the composite filaments with lower $\mathrm{ZrAA} / \mathrm{PAN}$ mass ratio. The average $\mathrm{t}-\mathrm{ZrO}_{2}$ grain size in $3 \mathrm{~mol} \% \mathrm{Y}_{2} \mathrm{O}_{3}-\mathrm{ZrO}_{2}$ nanofibers prepared at $900{ }^{\circ} \mathrm{C}$ from composite filaments with various $\mathrm{ZrAA} / \mathrm{PAN}$ mass ratios are $17.5 \mathrm{~nm}(0.1: 1), 17.7 \mathrm{~nm}(0.2: 1)$ and $18 \mathrm{~nm}(0.3: 1)$. A slight decrease in the average $\mathrm{t}-\mathrm{ZrO}_{2}$ grain size due to reduced $\mathrm{ZrAA} / \mathrm{PAN}$ mass ratio may be associated with a decrease in the contact surface between the grains due to a decrease in the resulting ceramic fibers diameter that negatively affects the diffusion process. Previously, a similar effect was observed for zirconia nanofibers made of composite filaments containing zirconium oxychloride and poly(ethylene oxide) [29]. Close values of the average grain size explain the similarity in the specific surface area of $3 \mathrm{~mol} \% \mathrm{Y}_{2} \mathrm{O}_{3}-\mathrm{ZrO}_{2}$ nanofibers fabricated from the composite filaments with ZrAA/PAN mass ratios of 0.3:1, 0.2:1 and 0.1:1. 


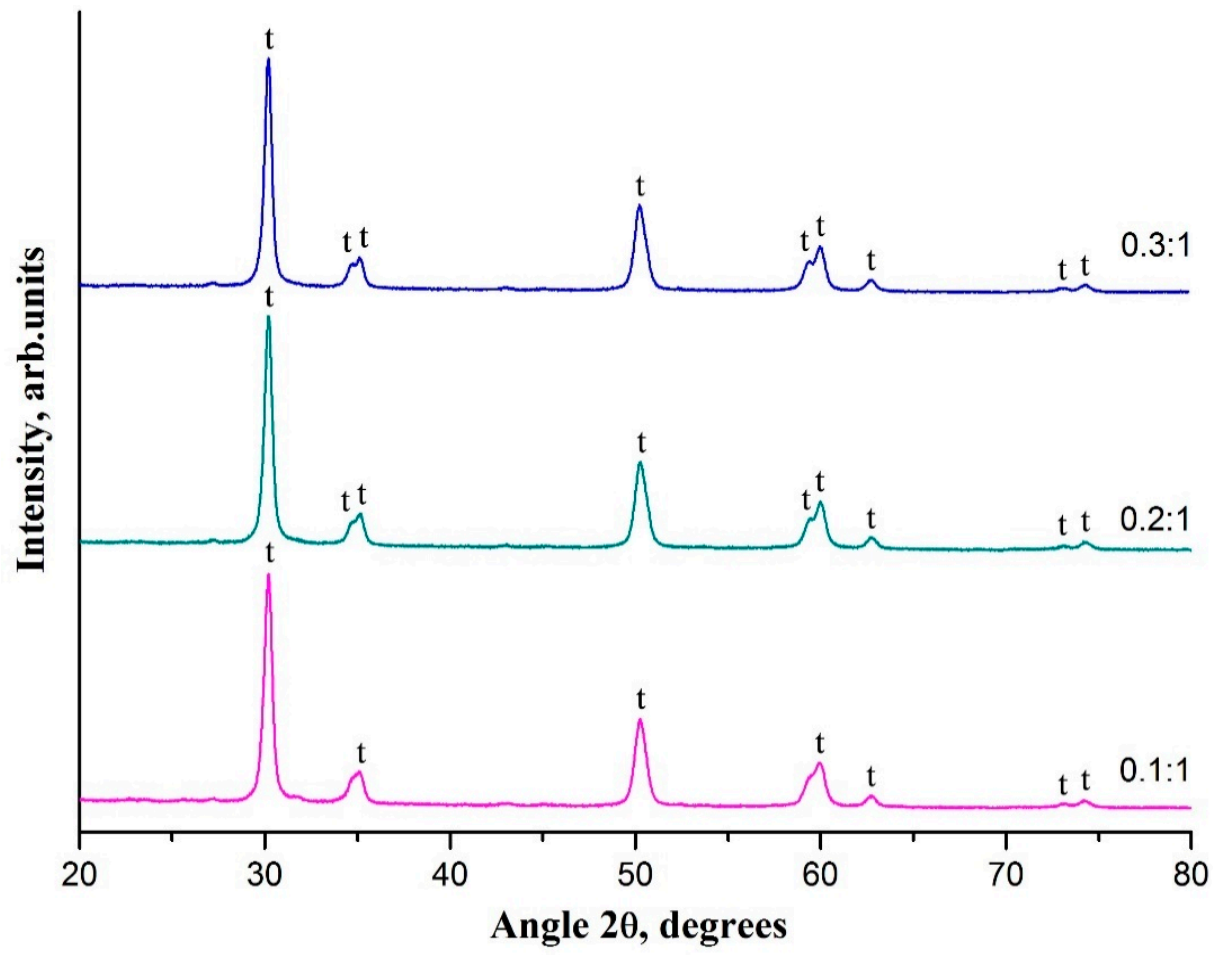

Figure 4. The XRD patterns of $3 \mathrm{~mol} \% \mathrm{Y}_{2} \mathrm{O}_{3}-\mathrm{ZrO}_{2}$ nanofibers prepared at $900{ }^{\circ} \mathrm{C}$ from the composite filaments with various $\mathrm{ZrAA} / \mathrm{PAN}$ mass ratios; $\mathrm{t}$ - tetragonal phase of $\mathrm{ZrO}_{2}$.

The phase composition of zirconia nanofibers changes dramatically if a dopant is not used. In the XRD pattern a large number of $\mathrm{m}-\mathrm{ZrO}_{2}$ peaks appear (Figure 5).

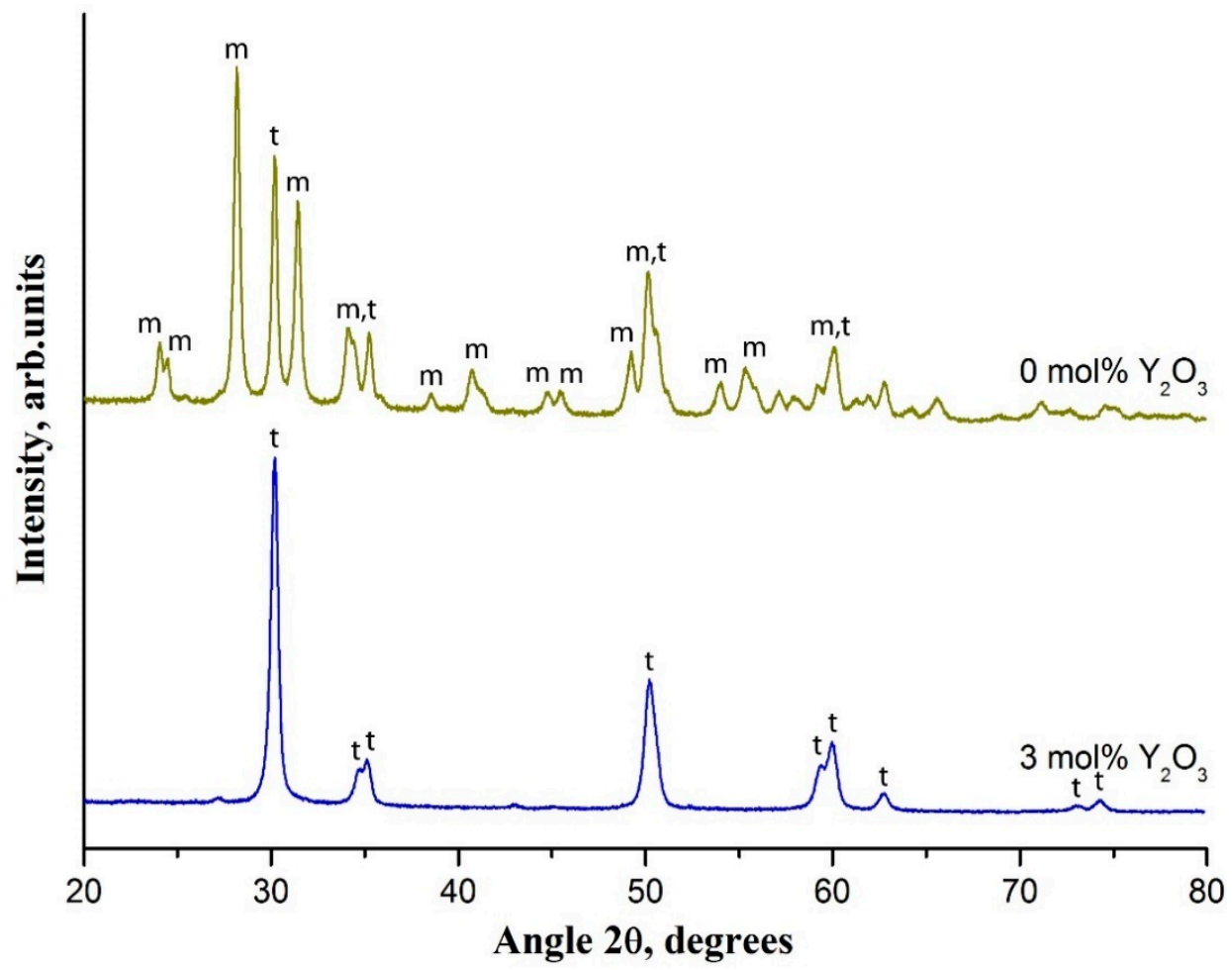

Figure 5. The $\mathrm{XRD}$ patterns of $3 \mathrm{~mol} \% \mathrm{Y}_{2} \mathrm{O}_{3}-\mathrm{ZrO}_{2}$ nanofibers and undoped ones prepared at $900{ }^{\circ} \mathrm{C}$; $\mathrm{t}$ and $\mathrm{m}$-tetragonal and monoclinic phases of $\mathrm{ZrO}_{2}$, respectively. 
The main characteristic peaks of $\mathrm{m}-\mathrm{ZrO}_{2}$ are located at $28.2^{\circ}$ and $31.5^{\circ}$. The undoped zirconia nanofibers contain $74 \%$ of $\mathrm{m}-\mathrm{ZrO}_{2}$ and $26 \%$ of $\mathrm{t}-\mathrm{ZrO}_{2}$ after calcination at $900{ }^{\circ} \mathrm{C}$. In [30] it was revealed that with an increase in the calcination temperature the content of $\mathrm{m}-\mathrm{ZrO}_{2}$ in undoped zirconia nanofibers rises reaching $100 \%$. It occurs due to $\mathrm{t}-\mathrm{ZrO}_{2} \rightarrow$ $\mathrm{m}-\mathrm{ZrO} \mathrm{r}_{2}$ transition induced by zirconia grain growth with an increase in the calcination temperature. Due to the size factor $\mathrm{t}-\mathrm{ZrO}_{2}$ is thermodynamically more favorable than $\mathrm{m}$ $\mathrm{ZrO}_{2}$ at amorphous $\mathrm{ZrO}_{2}$ crystallization [31]. According to Garvie's theory the transition probability of the metastable $\mathrm{t}-\mathrm{ZrO}_{2}$ phase into the $\mathrm{m}-\mathrm{ZrO}_{2}$ phase increases with the rise in zirconia grain size [32]. The $\mathrm{m}-\mathrm{ZrO}_{2}$ phase is stable at temperatures up to $1170{ }^{\circ} \mathrm{C}$ [33]. A dopant addition prevents this phase transition in zirconia nanofibers [34]. $\mathrm{The}^{\mathrm{t}-\mathrm{ZrO}_{2}}$ $\rightarrow \mathrm{m}-\mathrm{ZrO}_{2}$ transformation is accompanied with the volume expansion due to an increase in zirconia grain size [33]. It explains the larger average grain size of undoped zirconia nanofibers prepared at $900{ }^{\circ} \mathrm{C}$ compared to $3 \mathrm{~mol} \% \mathrm{Y}_{2} \mathrm{O}_{3}-\mathrm{ZrO}_{2}$ nanofibers prepared at the same temperature: $24 \mathrm{~nm}$ and $18 \mathrm{~nm}$, respectively. The larger grain size of undoped zirconia nanofibers explains their lower specific surface area compared with the $3 \mathrm{~mol} \%$ $\mathrm{Y}_{2} \mathrm{O}_{3}-\mathrm{ZrO}_{2}$ ones (11.3 and $15.1 \mathrm{~m}^{2} / \mathrm{g}$, respectively). This allows concluding that a small amount of yttria acts as an inhibitor of $\mathrm{ZrO}_{2}$ grain growth in nanofibers similarly to $\mathrm{Y}_{2} \mathrm{O}_{3}$ -stabilized zirconia bulk ceramics [35].

Figure 6 illustrates the load-displacement curves obtained for $3 \mathrm{~mol} \% \mathrm{Y}_{2} \mathrm{O}_{3}-\mathrm{ZrO}_{2}$ nanofiber mats calcined at different temperatures. It can be seen from Table 2 that the mat fabricated at $1100{ }^{\circ} \mathrm{C}$ possesses the highest values of hardness and Young's modulus.

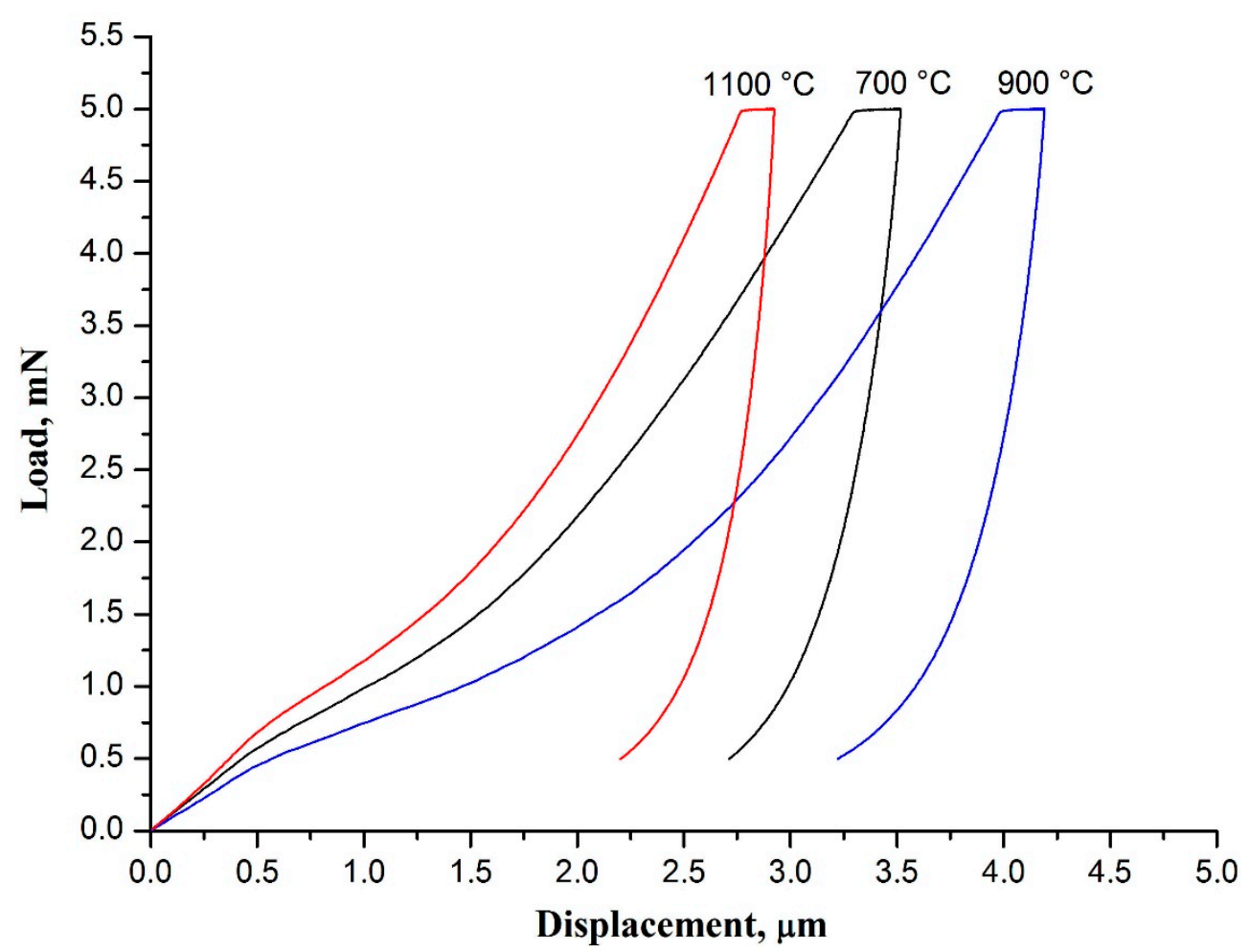

Figure 6. The load-displacement curves of $3 \mathrm{~mol} \% \mathrm{Y}_{2} \mathrm{O}_{3}-\mathrm{ZrO}_{2}$ nanofiber mats prepared at 700, 900 and $1100{ }^{\circ} \mathrm{C}$. 
Table 2. The mechanical characteristics of $3 \mathrm{~mol} \% \mathrm{Y}_{2} \mathrm{O}_{3}-\mathrm{ZrO}_{2}$ nanofiber mats calcined at different temperatures.

\begin{tabular}{ccc}
\hline Calcination Temperature, ${ }^{\circ} \mathbf{C}$ & Hardness, $\mathbf{M P a}$ & Young's Modulus, MPa \\
\hline 700 & $1.03 \pm 0.05$ & $171 \pm 4$ \\
900 & $0.86 \pm 0.05$ & $133 \pm 4$ \\
1100 & $1.25 \pm 0.11$ & $261 \pm 12$ \\
\hline
\end{tabular}

High calcination temperature leads to formation of junctions between nanofibers at the cross-points due to sintering, which negatively affects the nanofibers freedom of movement. As a result, the mat loses flexibility and its Young's modulus increases. Besides, the mat becomes harder and more brittle. Low calcination temperature is insufficient for nanofibers sintering at their cross-points as well as for zirconia grains sintering inside the filaments to form strong contacts. Thus, we suppose that there are no other bonds than the Van der Waals forces providing free movement of the nanofibers and the grains inside them. Therefore, zirconia nanofibrous mats calcined at low temperatures are more flexible than ones calcined at elevated temperatures. Flexible materials are known to be characterized by reduced Young's modulus [16]. Previously, it was found that the mat of yttria-stabilized zirconia nanofibers fabricated at $1000^{\circ} \mathrm{C}$ from composite filaments containing zirconium oxychloride/yttrium nitrate/poly(vinyl pyrrolidone was characterized by a lower ultimate strain in tensile testing than the one obtained at $800^{\circ} \mathrm{C}$, i.e., was more fragile [36].

The $3 \mathrm{~mol} \% \mathrm{Y}_{2} \mathrm{O}_{3}-\mathrm{ZrO}_{2}$ nanofibers produced at 700 and $900{ }^{\circ} \mathrm{C}$ have close average diameter values and differ in their average grain size. The smaller size provides a stronger connection between the grains due to a larger contact area, which hinders their free movement. The nanofibers become stiffer andtheir Young's modulus increases, respectively. As a result, nanofibrous mat Young's modulus increases too. The $3 \mathrm{~mol} \% \mathrm{Y}_{2} \mathrm{O}_{3}-\mathrm{ZrO}_{2}$ nanofibers prepared at $1100{ }^{\circ} \mathrm{C}$ have larger grains than filaments prepared at 700 and $900^{\circ} \mathrm{C}$. However, the connection between grains is stronger due to necks, which are formed at elevated calcination temperatures. Besides, sintering provides interfiber junctions at the cross-points as well. It explains the highest values of hardness and Young's modulus for the $3 \mathrm{~mol} \% \mathrm{Y}_{2} \mathrm{O}_{3}-\mathrm{ZrO}_{2}$ nanofiber mat fabricated at $1100{ }^{\circ} \mathrm{C}$.

Young's modulus of the fabricated $3 \mathrm{~mol} \% \mathrm{Y}_{2} \mathrm{O}_{3}-\mathrm{ZrO}_{2}$ nanofiber mats is three orders of magnitude lower than that of bulk $3 \mathrm{~mol} \% \mathrm{Y}_{2} \mathrm{O}_{3}-\mathrm{ZrO}_{2}$ ceramics [4]. This means that zirconia nanofibrous mats are more flexible than bulk zirconia ceramics. In [16] mats of $3 \mathrm{~mol} \% \mathrm{Y}_{2} \mathrm{O}_{3}$ $\mathrm{ZrO}_{2}$ nanofibers with the average diameter of $530 \pm 120 \mathrm{~nm}$ prepared using zirconium $n$-propoxide, yttrium acetate hexahydrate and polyvinylpyrrolidone were characterized by Young's modulus of $1.11 \pm 0.24 \mathrm{MPa}$ obtained by means of microindentation. Different Young's modulus values of the mats presented in this article and those fabricated in [16] can be associated with the different average diameter of the zirconia nanofibers forming the mats. It is shown below that Young's modulus of the mat increases with the decrease in the average diameter of fibers.

The load-displacement curves obtained for $3 \mathrm{~mol} \% \mathrm{Y}_{2} \mathrm{O}_{3}-\mathrm{ZrO}_{2}$ nanofiber mats prepared at the same temperature from the mats of composite filaments with different $\mathrm{ZrAA} / \mathrm{PAN}$ mass ratios are presented in Figure 7. 


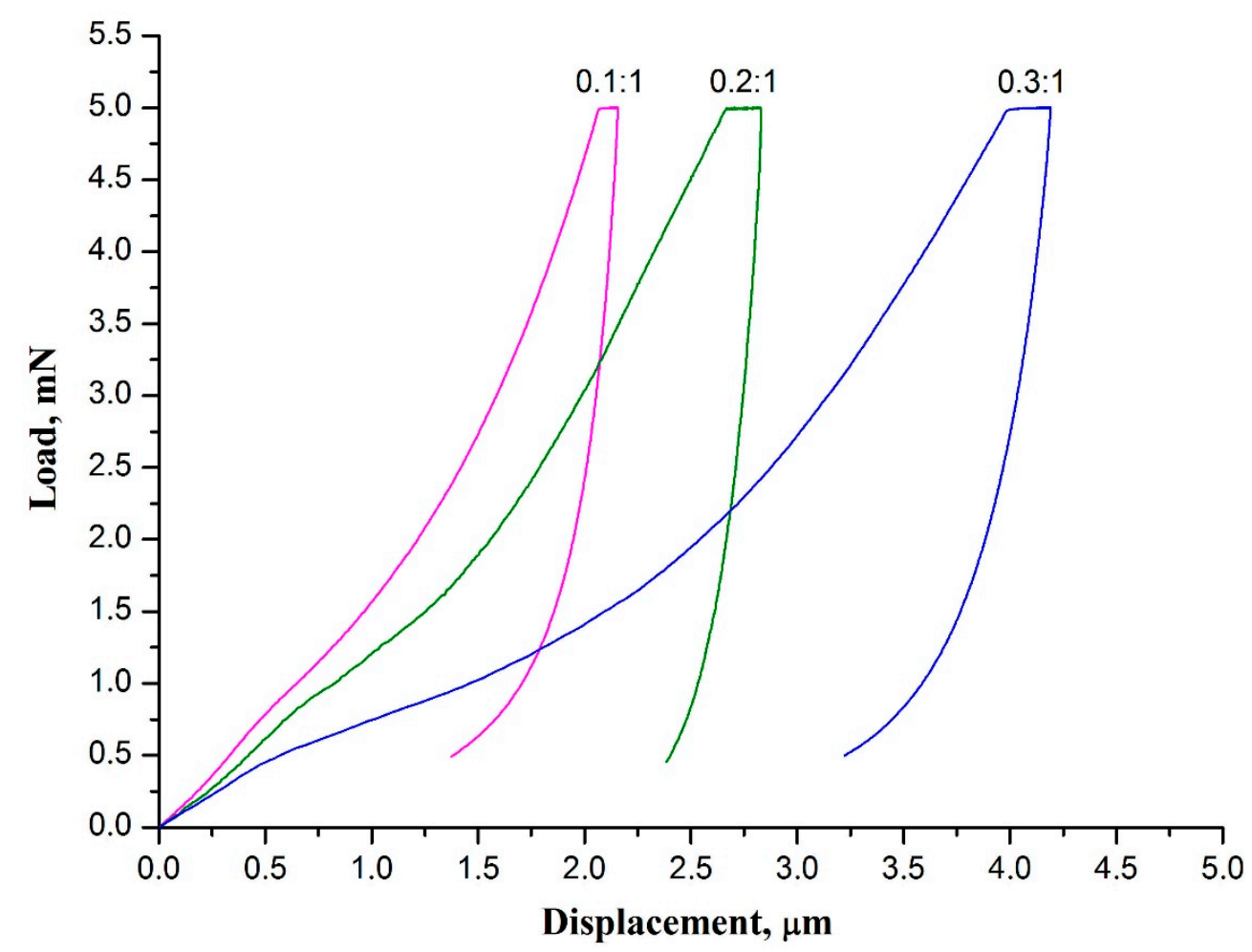

Figure 7. The load-displacement curves of $3 \mathrm{~mol} \% \mathrm{Y}_{2} \mathrm{O}_{3}-\mathrm{ZrO}_{2}$ nanofiber mats prepared at $900{ }^{\circ} \mathrm{C}$ from the mats of composite filaments with different $\mathrm{ZrAA} / \mathrm{PAN}$ mass ratio.

The $3 \mathrm{~mol} \% \mathrm{Y}_{2} \mathrm{O}_{3}-\mathrm{ZrO}_{2}$ nanofibers fabricated from composite filaments with different $\mathrm{ZrAA} / \mathrm{PAN}$ mass ratios possess identical phase composition and consist of similar-sized zirconia grains, but differ in their average diameter, which increases with the rise in $\mathrm{ZrAA} / \mathrm{PAN}$ mass ratio. A decrease in the zirconia nanofibers diameter associated with a decrease in ZrAA/PAN mass ratio results in the rise in both hardness and Young's modulus of zirconia nanofibrous mat (Table 3). A decrease in ZrAA/PAN mass ratio produces thinner zirconia nanofibers which, in its turn, results in the rise in both hardness and Young's modulus of a zirconia nanofibrous mat (Table 3). The higher values of hardness and Young's modulus of the mat formed by thinner zirconia nanofibers may be explained by a reduced number of flaws. The presence of flaws in the material significantly worsens the mechanical properties of ceramics by promoting stress concentration [37]. Ceramic filaments with reduced diameter contain fewer flaws thus improving their mechanical characteristics. An increase in $\mathrm{TiO}_{2}$ nanofibers Young's modulus and $\mathrm{Al}_{2} \mathrm{O}_{3}$ nanofibers tensile strength with a decrease in their diameter was observed in $[38,39]$. In $[8,36]$ it was reported that the tensile strength of nanofibrous membranes of yttria-stabilized zirconia increases when the diameter of nanofibers decreases.

Table 3. The mechanical characteristics of $3 \mathrm{~mol} \% \mathrm{Y}_{2} \mathrm{O}_{3}-\mathrm{ZrO}_{2}$ nanofiber mats prepared at $900{ }^{\circ} \mathrm{C}$ from the mats of composite filaments with different $\mathrm{ZrAA} / \mathrm{PAN}$ mass ratio.

\begin{tabular}{ccc}
\hline ZrAA/PAN Mass Ratio & Hardness, MPa & Young's Modulus, MPa \\
\hline $0.1: 1$ & $1.67 \pm 0.09$ & $362 \pm 13$ \\
$0.2: 1$ & $1.11 \pm 0.06$ & $280 \pm 8$ \\
$0.3: 1$ & $0.86 \pm 0.05$ & $133 \pm 4$ \\
\hline
\end{tabular}

The results of nanoindentation measurement indicate that the hardness and Young's modulus of zirconia nanofibrous mats are sensitive to phase composition of filaments (Figure 8). 


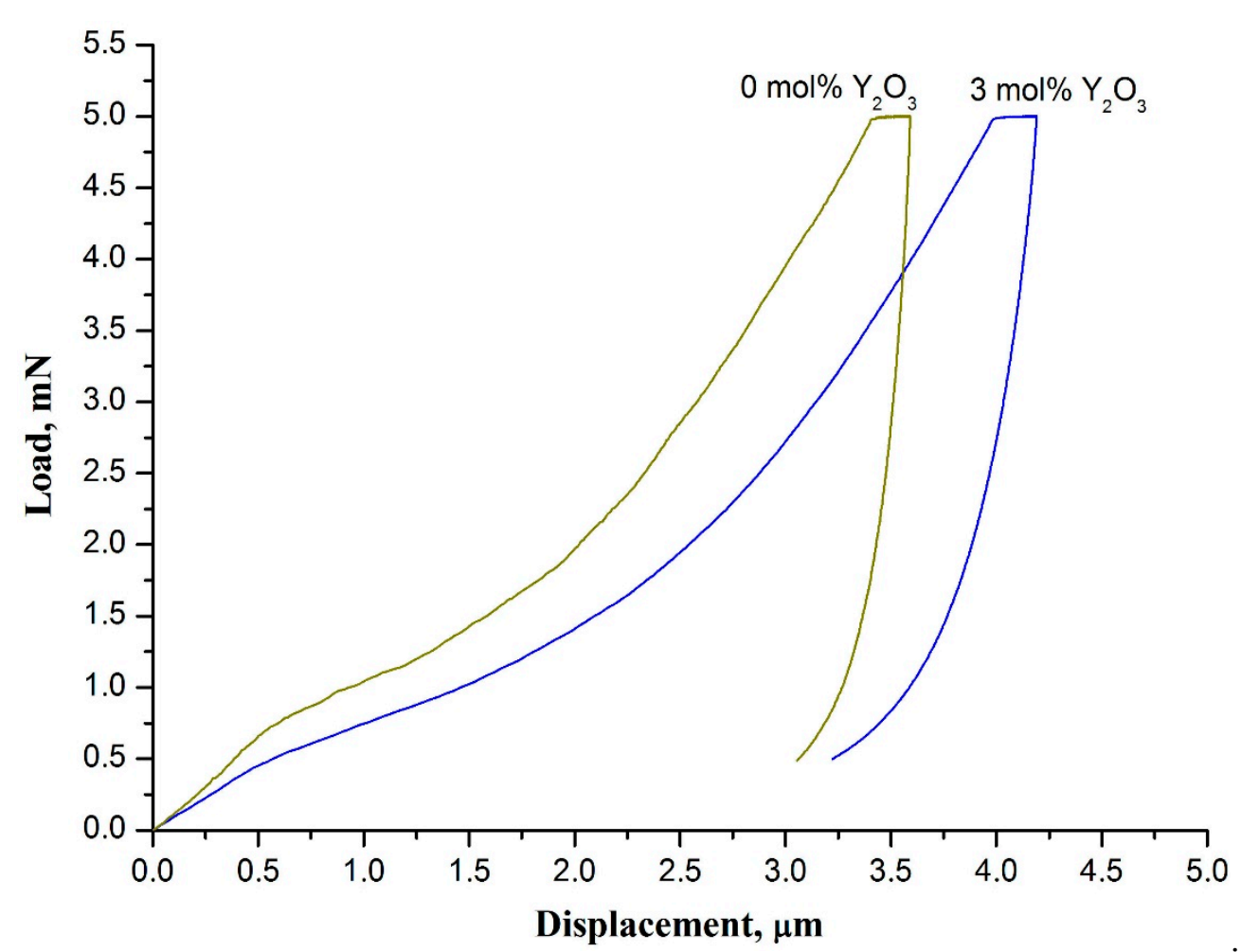

Figure 8. The load-displacement curves of $3 \mathrm{~mol} \% \mathrm{Y}_{2} \mathrm{O}_{3}-\mathrm{ZrO}_{2}$ nanofiber mat and undoped zirconia nanofiber mat prepared at $900{ }^{\circ} \mathrm{C}$.

Regarding the example of the $3 \mathrm{~mol} \% \mathrm{Y}_{2} \mathrm{O}_{3}-\mathrm{ZrO}_{2}$ nanofiber mat and the undoped zirconia nanofiber mat both calcined at $900{ }^{\circ} \mathrm{C}$ it is revealed that Young's modulus and hardness of the mat of fully tetragonal zirconia nanofibers $(E=133 \pm 4 \mathrm{MPa}, H=0.86 \pm 0.05 \mathrm{MPa})$ are less than those of the mat of nanofibers mostly comprised of $\mathrm{m}-\mathrm{ZrO}_{2}(E=300 \pm 10 \mathrm{MPa}$, $H=0.95 \pm 0.04 \mathrm{MPa}$ ). The higher Young's modulus and hardness of the undoped zirconia nanofiber mat indicate that it is stiffer and more brittle than the $3 \mathrm{~mol} \% \mathrm{Y}_{2} \mathrm{O}_{3}-\mathrm{ZrO}_{2}$ nanofiber mat prepared at the same temperature and containing no $\mathrm{m}-\mathrm{ZrO}_{2}$. As mentioned above, $\mathrm{t}-\mathrm{ZrO} \mathrm{r}_{2} \rightarrow \mathrm{m}-\mathrm{ZrO}_{2}$ transition occurs if undoped zirconia nanofibers are calcined at $900{ }^{\circ} \mathrm{C}$. Phase transition is accompanied with volume expansion which creates large internal stresses. The latter may induce nanofiber damage. It results in greater fragility of undoped zirconia nanofiber mats compared to stabilized zirconia nanofiber mats. Thus, it can be concluded that the presence of $\mathrm{m}-\mathrm{ZrO}_{2}$ in zirconia nanofibers worsens the strength of both zirconia nanofibers themselves and the mats they form. An increase in the calcination temperature leads to the rise in the fragility of individual undoped zirconia nanofibers and their mats, respectively, due to $\mathrm{m}-\mathrm{ZrO}_{2}$ content increase. In [30,36] it has been revealed that the mats of fully monoclinic zirconia nanofibers manufactured at $1300{ }^{\circ} \mathrm{C}$ crumble into powder upon preparation.

\section{Conclusions}

Zirconia nanofiber mats containing filaments with the average diameter of less than $100 \mathrm{~nm}$ were fabricated. It is found that the hardness and Young's modulus of the mats are sensitive to the microstructure, phase composition and average diameter of the zirconia nanofibers. A decrease in the diameter of nanofibers and an increase in the heat treatment temperature leads to an increase in the hardness and Young's modulus of the mats. The hardness and Young's modulus of the prepared zirconia nanofiber mats vary from 0.86 to $1.67 \mathrm{MPa}$ and from 133 to $362 \mathrm{MPa}$, respectively, wherein an increase in hardness is accompanied by the rise in Young's modulus. The obtained results indicate the possibility of controlling the hardness and Young's modulus of nonwoven zirconia membranes via varying the calcination temperature and intermediate filament composition. 
Author Contributions: V.V.R.: investigation, writing-original draft preparation, editing; A.I.T.: project administration, investigation; S.S.R.: investigation, formal analysis; V.V.K.: investigation, formal analysis; Y.I.G.: methodology, supervision. All authors have read and agreed to the published version of the manuscript.

Funding: The reported study was funded by Russian Foundation for Basic Research (RFBR) according to the research project No. 18-29-17047 and partially supported by the Ministry of Science and Higher Education of the Russian Federation in the frame work of agreement No. 075-15-2021-709.

Institutional Review Board Statement: Not applicable.

Informed Consent Statement: Not applicable.

Data Availability Statement: All data included in this study are available upon request from the corresponding author.

Conflicts of Interest: The authors declare no conflict of interest.

\section{References}

1. Xue, J.; Wu, T.; Dai, Y.; Xia, Y. Electrospinning and electrospun nanofibers: Methods, materials, and applications. Chem. Rev. 2019, 119, 5298-5415. [CrossRef] [PubMed]

2. Esfahani, H.; Jose, R.; Ramakrishna, S. Electrospun ceramic nanofiber mats today: Synthesis, properties, and applications. Materials 2017, 10, 1238. [CrossRef] [PubMed]

3. Zhang, X.; Wu, X.; Shi, J. Additive manufacturing of zirconia ceramics: A state-of-the-art review. J. Mater. Res. Technol. 2020, 9 , 9029-9048. [CrossRef]

4. Gautam, C.; Joyner, J.; Gautam, A.; Rao, J.; Vajtai, R. Zirconia based dental ceramics: Structure, mechanical properties, biocompatibility and applications. Dalton Trans. 2016, 45, 19194-19215. [CrossRef]

5. Koo, J.Y.; Lim, Y.; Kim, Y.B.; Byun, D.; Lee, W. Electrospun yttria-stabilized zirconia nanofibers for low-temperature solid oxide fuel cells. Int. J. Hydrog. Energy 2017, 42, 15903-15907. [CrossRef]

6. Zhi, M.; Mariani, N.; Gemmen, R.; Gerdes, K.; Wu, N. Nanofiber scaffold for cathode of solid oxide fuel cell. Energy Environ. Sci. 2011, 4, 417-420. [CrossRef]

7. Jing, P.; Liu, M.; Wang, P.; Yang, J.; Tang, M.; He, C.; Pu, Y.; Liu, M. Flexible nonwoven $\mathrm{ZrO}_{2}$ ceramic membrane as an electrochemically stable and flame-resistant separator for high-power rechargeable batteries. Chem. Eng. J. 2020, $388,124259$. [CrossRef]

8. Mao, X.; Bai, Y.; Yu, J.; Ding, B. Flexible and highly temperature resistant polynanocrystalline zirconia nanofibrous membranes designed for air filtration. J. Am. Ceram. Soc. 2016, 99, 2760-2768. [CrossRef]

9. Tang, Y.; Liu, Z.; Zhao, K.; Fu, S. Adsorption and separation properties of positively charged $\mathrm{ZrO}_{2}$ nanofibrous membranes fabricated by electrospinning. RSC Adv. 2017, 7, 42505-42512. [CrossRef]

10. Ávila-Martínez, A.K.; Roque-Ruiz, J.H.; Torres-Pérez, J.; Medellín-Castillo, N.A.; Reyes-López, S.Y. Allura Red dye sorption onto electrospun zirconia nanofibers. Environ. Technol. Innov. 2020, 18, 100760. [CrossRef]

11. Jin, X.; Yuan, K.; Wang, X.; Li, C. Electrospun mesoporous zirconia nanofibers as effective biomimetic haloperoxidase for pollution conversion and separation. Surf. Interfaces 2021, 26, 101358. [CrossRef]

12. Lee, C.; Shul, Y.-G.; Einaga, H. Silver and manganese oxide catalysts supported on mesoporous $\mathrm{ZrO}_{2}$ nanofiber mats for catalytic removal of benzene and diesel soot. Catal. Today 2017, 281 Pt 3, 460-466. [CrossRef]

13. Ruiz-Rosas, R.; Bedia, J.; Rosas, J.M.; Lallave, M.; Loscertales, I.G.; Rodríguez-Mirasol, J.; Cordero, T. Methanol decomposition on electrospun zirconia nanofibers. Catal. Today 2012, 187, 77-87. [CrossRef]

14. Xia, J.; Guo, H.; Cheng, M.; Chen, C.; Wang, M.; Xiang, Y.; Li, T.; Traversa, E. Electrospun zirconia nanofibers for enhancing the electrochemical synthesis of ammonia by artificial nitrogen fixation. J. Mater. Chem. A 2021, 9, 2145-2151. [CrossRef]

15. Li, W.; Ren, Y.; Guo, Y. $\mathrm{ZrO}_{2} / \mathrm{ZnO}$ nanocomposite materials for chemiresistive butanol sensors. Sens. Actuators B-Chem. 2020, 308, 127658. [CrossRef]

16. Gazquez, G.C.; Chen, H.; Veldhuis, S.A.; Solmaz, A.; Mota, C.; Boukamp, B.A.; van Blitterswijk, C.A.; ten Elshof, J.E.; Moroni, L. Flexible yttrium-stabilized zirconia nanofibers offer bioactive cues for osteogenic differentiation of human mesenchymal stromal cells. ACS Nano 2016, 10, 5789-5799. [CrossRef] [PubMed]

17. Du, Z.; Zhou, X.; Ye, P.; Zeng, X.; Gan, C.L. Shape-memory actuation in aligned zirconia nanofibers for artificial muscle applications at elevated temperatures. ACS Appl. Nano Mater. 2020, 3, 2156. [CrossRef]

18. Guo, H.; Chen, Y.; Li, Y.; Zhou, W.; Xu, W.; Pang, L.; Fan, X.; Jiang, S. Electrospun fibrous materials and their applications for electromagnetic interference shielding: A review. Compos. Part A Appl. Sci. Manuf. 2021, 143, 106309. [CrossRef]

19. Yildirim, F.; Orhan, Z.; Khalili, S.; Chenari, H.M.; Aydoğan, S. Self-powered $\mathrm{ZrO}_{2}$ nanofibers/n-Si photodetector with high on/off ratio for detecting very low optical signal. J. Phys. D Appl. Phys. 2021, 54, 475101. [CrossRef] 
20. Lee, N.-W.; Yoon, K.R.; Lee, J.-Y.; Park, Y.; Pyo, S.-J.; Kim, G.-Y.; Ha, D.-H.; Ryu, W.-H. Highly conductive off-stoichiometric zirconium oxide nanofibers with controllable crystalline structures and bandgaps and improved electrochemical activities. ACS Appl. Energy Mater. 2019, 2, 3513. [CrossRef]

21. Castkova, K.; Maca, K.; Sekaninova, J.; Nemcovsky, J.; Cihlar, J. Electrospinning and thermal treatment of yttria doped zirconia fibres. Ceram. Int. 2017, 43, 7581-7587. [CrossRef]

22. Rodaev, V.V.; Razlivalova, S.S.; Tyurin, A.I.; Zhigachev, A.O.; Golovin, Y.I. Microstructure and phase composition of yttriastabilized zirconia nanofibers prepared by high-temperature calcination of electrospun zirconium acetylacetonate/yttrium nitrate/polyacrylonitrile fibers. Fibers 2019, 7, 82. [CrossRef]

23. Stanishevsky, A.; Yager, R.; Tomaszewska, J.; Binczarski, M.; Maniukiewicz, W.; Witońska, I.; Lukas, D. Structure and mechanical properties of nanofibrous $\mathrm{ZrO}_{2}$ derived from alternating field electrospun precursors. Ceram. Int. 2019, 45, 18672-18682. [CrossRef]

24. Park, S.-J.; Chase, G.G.; Jeong, K.-U.; Kim, H.Y. Mechanical properties of titania nanofiber mats fabricated by electrospinning of sol-gel precursor. J. Sol-Gel Sci. Technol. 2010, 54, 188-194. [CrossRef]

25. Lu, H.; Zhang, T.; Wang, X.P.; Fang, Q.F. Electrospun submicron bioactive glass fibers for bone tissue scaffold. J. Mater Sci. Mater. Med. 2009, 20, 793-798. [CrossRef]

26. Paietta, R.C.; Campbell, S.E.; Ferguson, V.L. Influences of spherical tip radius, contact depth, and contact area on nanoindentation properties of bone. J. Biomech. 2011, 44, 285-290. [CrossRef] [PubMed]

27. Fischer-Cripps, A.C. Nanoindentation, 3rd ed.; Springer: New York, NY, USA, 2011; p. 282.

28. Arshad, S.N.; Naraghi, M.; Chasiotis, I. Strong carbon nanofibers from electrospun polyacrylonitrile. Carbon 2011, 49, 1710-1719. [CrossRef]

29. Rodaev, V.V.; Zhigachev, A.O.; Korenkov, V.V.; Golovin, Y.I. The influence of zirconia precursor/binding polymer mass ratio in the intermediate electrospun composite fibers on the phase transformation of final zirconia nanofibers. Phys. Status Solidi A 2016, 213, 2352-2355. [CrossRef]

30. Rodaev, V.V.; Razlivalova, S.S.; Zhigachev, A.O.; Vasyukov, V.M.; Golovin, Y.I. Preparation of zirconia nanofibers by electrospinning and calcination with zirconium acetylacetonate as precursor. Polymers 2019, 11, 1067. [CrossRef] [PubMed]

31. Guo, G.-Y.; Chen, Y.-L. Unusual structural phase transition in nanocrystalline zirconia. Appl. Phys. A 2006, 84, 431-437. [CrossRef]

32. Garvie, R.C. The occurrence of metastable tetragonal zirconia as a crystallite size effect. J. Phys. Chem. 1965, 69, 1238-1243. [CrossRef]

33. Chevalier, J.; Gremillard, L.; Virkar, A.V.; Clarke, D.R. The tetragonal-monoclinic transformation in zirconia: Lessons learned and future trends. J. Am. Ceram. Soc. 2009, 92, 1901-1920. [CrossRef]

34. Sun, G.-X.; Liu, F.-T.; Bi, J.-Q.; Wang, C.-A. Electrospun zirconia nanofibers and corresponding formation mechanism study. J. Alloys Compd. 2015, 649, 788-792. [CrossRef]

35. Lange, F.F. Transformation-toughened $\mathrm{ZrO}_{2}$ : Correlations between grain size control and composition in the system $\mathrm{ZrO}_{2}-\mathrm{Y}_{2} \mathrm{O}_{3}$. J. Am. Ceram. Soc. 1986, 69, 240-242. [CrossRef]

36. Chen, Y.; Mao, X.; Shan, H.; Yang, J.; Wang, H.; Chen, S.; Tian, F.; Yu, J.; Ding, B. Free-standing zirconia nanofibrous membranes with robust flexibility for corrosive liquid filtration. RSC Adv. 2014, 4, 2756-2763. [CrossRef]

37. Eckel, Z.C.; Zhou, C.; Martin, J.H.; Jacobsen, A.J.; Carter, W.B.; Schaedler, T.A. Additive manufacturing of polymer-derived ceramics. Science 2016, 351, 58-62. [CrossRef]

38. Lee, S.-H.; Tekmen, C.; Sigmund, W.M. Three-point bending of electrospun $\mathrm{TiO}_{2}$ nanofibers. Mater. Sci. Eng. A 2005, 398, 77-81. [CrossRef]

39. Sun, W. Fabrication and Characterization of Electrospun Alumina Nanofibre Reinforced Polycarbonate Composites. Ph.D. Thesis, Queen Mary University of London, London, UK, 2017; 201p. 